\title{
Excitatory Amino Acid Binding Sites in the Caudate Nucleus and Frontal Cortex of Huntington's Disease
}

\author{
Leon S. Dure IV, MD, Anne B. Young, MD, PhD, and John B. Penney, MD
}

\begin{abstract}
Huntington's disease is a dominantly inherited, progressive neurodegenerative disorder causing marked pathology in the basal ganglia. The pathophysiology of the selective neuronal death is as yet unknown, but evidence suggests that the neurotoxicity may result from endogenous substances acting at excitatory amino acid receptors. Previous data have shown a selective decrease in binding to one class of glutamate receptors, the $N$-methyl-D-aspartate (NMDA) receptor in the putamen of Huntington's disease. The present study was undertaken to determine the relative density of binding to all of the currently defined subpopulations of excitatory amino acid receptors in the caudate nuclei and frontal cortex of patients with Huntington's disease and of control subjects, using quantitative in vitro autoradiography. NMDA, MK-801, glycine, kainate, and $\alpha$-amino-3-hydroxy-5-methylisoxazole propionic acid (AMPA) receptor binding were all decreased to a similar extent $(50-60 \%)$. Binding to the metabotropic quisqualate receptor and to the non-NMDA, nonkainate, nonquisqualate (NNKQ) site was decreased nonsignificantly by $31 \%$ and $26 \%$, respectively. Autoradiograms of NMDA, MK-801, AMPA, kainate, metabotropic, and NNKQ receptors in caudates revealed an inhomogeneous pattern of binding that is different from the binding pattern seen in control caudates. Binding to all receptor subtypes was the same in the frontal cortex from Huntington's disease patients and control subjects. The data suggest that no single excitatory amino acid receptor is selectively decreased in the caudate of Huntington's disease.
\end{abstract}

Dure LS IV, Young AB, Penney JB. Excitatory amino acid-binding sites in the caudate nucleus and frontal cortex of Huntington's disease. Ann Neurol 1991;30:785-793

Huntington's disease (HD) is a dominantly inherited neurodegenerative disorder with complete penetrance, onset usually in midlife, adventitious movements, progressive dementia, and premature death [1]. Behavioral disturbances may precede or accompany the illness. The HD gene is located on the short arm of chromosome 4 , but the gene product and its relation to the pathophysiology of HD are as yet unknown. Pathologically, caudate atrophy due to a loss of medium-sized spiny neurons is the hallmark of HD, with less marked neuronal loss in the putamen $[2,3]$. Cortical neuronal loss has also been described [4]. Striatal cell loss is not uniform; there is a dramatic loss of medium spiny neurons and preservation of small aspiny neurons containing neuropeptide $\mathrm{Y}$ and somatostatin, as well as the large cholinergic aspiny neurons [5].

To explain the pattern of neuronal cell loss in $\mathrm{HD}$, a hypothesis has been put forward involving the neurotoxicity of excitatory amino acid (EAA) neurotransmitters. These neurotransmitters, including glutamate and possibly aspartate, are the primary afferent transmitters to the striatum from the cortex [6]. EAA neurotoxicity is thought to play a role in hypoxia-ischemia [7], domoic acid-induced encephalopathy [8], and lathyrism $[9,10]$. Experimental evidence suggests that the pathophysiology of HD could be due to EAA excitotoxicity [11-18]. In the rat and monkey, administration of EAA agonists produces a lesion that is pathologically and immunohistochemically similar to that found in HD, with selective loss of medium-sized spiny neurons and sparing of somatostatin, neuropeptide $Y$, and cholinergic interneurons $[18,19]$. Fibers of passage within the caudate are unaffected.

EAA receptors are defined pharmacologically as either $N$-methyl-D-aspartate (NMDA) or non-NMDA receptors, depending on their affinity for NMDA [20]. Two other binding sites associated with the NMDA receptor complex are the strychnine-insensitive glycine site, and the phencyclidine (PCP) receptor [21]. The non-NMDA receptors are further subdivided into ionotropic quisqualate receptors, also known as the $\alpha$-amino-3-hydroxy-5-methylisoxazole propionic acid (AMPA) receptors, metabotropic quisqualate recep-
From the Department of Neurology, University of Michigan, Ann Arbor, MI.

Received Mar 11, 1991, and in revised form May 14. Accepted for publication May 21, 1991.
Address correspondence to Dr Dure, Massachusetts General Hospital, Neurology Research, Wellman 415, Boston, MA 02114. 
tors (associated with phosphoinositide metabolism), and kainate receptors $[20,22-24]$. Finally, a site that has been identified pharmacologically represents the specific binding of glutamate in the presence of saturable concentrations of NMDA, quisqualate, and kainate. This non-NMDA-, nonkainate-, nonquisqualatesensitive (NNKQ) site is as yet physiologically uncharacterized [25].

In $\mathrm{HD}$, there is a decrease in total $\left[{ }^{3} \mathrm{H}\right]$ glutamate binding $[26,27]$. Using more specific assays for glutamate receptor subpopulations, Young and colleagues determined the densities of total glutamate, NMDAsensitive, and quisqualate-sensitive receptor binding in putamen from patients with $\mathrm{HD}$, using quantitative in vitro receptor autoradiography [28]. The authors found a decrease in receptor binding to both the NMDA and non-NMDA receptors in HD, compared to control specimens. Of significance was the finding that NMDA receptor binding was decreased by more than $90 \%$, while both non-NMDA receptor binding and total glutamate binding were decreased by $67 \%$. The latter decreases were commensurate with the decline in binding seen in this same study for muscarinic cholinergic receptors, gamma-aminobutyric acid $\mathrm{A}\left(\mathrm{GABA}_{\mathrm{A}}\right)$ receptors, and benzodiazepine receptors. The finding of selective depletion of NMDA receptors was considered consistent with the hypothesis that NMDA receptor-mediated glutamate excitotoxicity plays a role in the pathogenesis of HD.

The purpose of the present study was to further characterize the changes in glutamate receptor populations in HD caudate and frontal cortex using more recently developed quantitative in vitro receptor autoradiographic binding assays specific for the NMDA, AMPA, kainate, metabotropic, and NNKQ receptors. Additionally, the strychnine-insensitive glycine site and PCP site were studied in both HD and control specimens.

\section{Materials and Methods \\ Tissue}

Blocks of tissue containing either caudate nucleus or frontal cortex from HD and control brains were selected from the University of Michigan Brain Bank, and coded (by J. B. P.) for analysis (Table 1). HD brains were pathologically graded by the criteria of Vonsattel and colleagues [2]. The mean age at the time of death ( \pm standard deviation [SD]) for the patients with $\mathrm{HD}$ was $50 \pm 21$ (range, 11-88) years, and for the control subjects, $60 \pm 21$ (range, 22-87) years. The postmortem delay $( \pm \mathrm{SD}$ ) for the patients and control subjects was $15 \pm 6$ (range, 6-24) hours and $16 \pm 7$ (range, 4-23) hours, respectively. The tissue blocks were kept frozen at $-70^{\circ} \mathrm{C}$ until they were thawed to $-20^{\circ} \mathrm{C}$ for sectioning.

For each receptor assay, blocks were cut into 20 - $\mu$ m-thick sections and thaw-mounted onto triple-submerged gelatincoated slides. Slides were stored at $-20^{\circ} \mathrm{C}$ for no longer than 48 hours prior to receptor autoradiography.
Table 1. Characteristics of Control and Huntington's Disease (HD) Brains

\begin{tabular}{llll}
\hline Brain Type & $\begin{array}{l}\text { Disease } \\
\text { Grade }^{\mathrm{a}}\end{array}$ & $\begin{array}{l}\text { Mean Age } \\
\pm \text { SD }(\mathrm{yr})\end{array}$ & $\begin{array}{l}\text { Postmortem } \\
\text { Delay } \pm \text { SD } \\
(\mathrm{hr})^{\mathrm{b}}\end{array}$ \\
\hline Control $(\mathrm{n}=12)$ & $\mathrm{N} / \mathrm{A}$ & $60 \pm 21$ & $16 \pm 7$ \\
& & & \\
HD $(\mathrm{n}=14)$ & $2(\mathrm{n}=5)$ & $68 \pm 16$ & \\
& $3(\mathrm{n}=5)$ & $59 \pm 5$ & $15 \pm 6$ \\
& $4(\mathrm{n}=4)$ & $25 \pm 5$ & \\
\hline
\end{tabular}

${ }^{2}$ Parhological grade according to the criteria of Vonsattel and colleagues [2].

benotes the time from death of the patient until the time the brain tissue was frozen at $-70^{\circ} \mathrm{C}$

$\mathrm{N} / \mathrm{A}=$ not applicable.

Owing to the scarcity of tissue, not all assays could be done in every brain. A total of $14 \mathrm{HD}$ brains and 12 control brains were used for assays of the caudate nucleus. The NNKQ assay was performed on $4 \mathrm{HD}$ and 7 control caudate nuclei. Six HD and 4 control brains were used for the assays in frontal cortex.

\section{Receptor Assays}

Tritiated glutamate, glycine, and kainate were obtained from Amersham (Arlington Heights, IL), and [ $\left.{ }^{3} \mathrm{H}\right] \mathrm{AMPA}$ and $\left[{ }^{3} \mathrm{H}\right] \mathrm{MK}-801$ were obtained from Dupont, New England Nuclear (Boston, MA). 3-(( \pm$)$-2-Carboxypiperazin4-yl)-propyl-1-phosphonic acid (CPP), quisqualic acid, and NMDA were purchased from Cambridge Research Biochemicals (Cambridge, UK), and MK-801 was a generous gift from Dr L. L. Iversen of Merck, Sharp \& Dohme Research Lab (Essex, UK). AMPA was obtained from Research Biochemicals (Natick, MA). All other reagents for buffers were manufactured by Sigma Chemical (St Louis, MO).

The buffers and incubation conditions for each assay are listed in Table 2. For NMDA, AMPA, glycine, metabotropic, NNKQ site, and kainate binding, assays were performed by prewashing the slides in buffer at $4^{\circ} \mathrm{C}$ for 30 minutes, then air-drying them prior to incubation. Incubations were performed at $4^{\circ} \mathrm{C}$ for 45 minutes (with the exception of glycine receptor binding, which required a 30 -minute incubation), followed by a rapid rinse with four 4-ml aliquots of buffer, and two $2-\mathrm{ml}$ aliquots of $2.5 \%$ glutaraldehyde in acetone. The slides were dried rapidly under hot air ( 10 to 12 seconds for each slide).

PCP receptor binding was measured with the ligand $\left[{ }^{3} \mathrm{H}\right] \mathrm{MK}-801$, and required a prewash of 30 minutes at $4{ }^{\circ} \mathrm{C}$, an incubation of 120 minutes at room temperature, and a rinse time of 80 minutes at $4^{\circ} \mathrm{C}$. These slides were not rinsed with glutaraldehyde/acetone.

After each assay, slides were apposed to $\mathrm{Hyperfilm}^{-3} \mathrm{H}$ (Amersham) in $\mathrm{x}$-ray cassettes along with standards of known radioactivity. Exposure time varied from 3 to 8 weeks. When exposure was completed, films were developed in D-19 (Eastman Kodak, Rochester, NY), fixed and dried, and the resulting images were quantified with respect to radioactive binding [29,30] using a computer-based video image analysis system (Imaging Research, St Catherines, Ontario, Canada). To obtain an average value for binding throughout the area of interest (caudate or cortical mantle), the entire structure 


\begin{tabular}{|c|c|c|c|c|c|}
\hline Receptor & Buffer & Temperature & $\begin{array}{l}\text { Incubation } \\
\text { Time (min) }\end{array}$ & Binding Conditions & $\begin{array}{l}\text { Displacer for } \\
\text { Nonspecific } \\
\text { Binding }\end{array}$ \\
\hline NMDA & $50 \mathrm{mM}$ Tris-acetate & $4^{\circ} \mathrm{C}$ & 45 & $\begin{array}{l}45 \mathrm{nM}\left[{ }^{3} \mathrm{H}\right] \text { glutamate, } \\
2.5 \mu \mathrm{M} \text { quisqualate, } \\
1 \mu \mathrm{M} \text { kainate }\end{array}$ & $100 \mu \mathrm{M} \mathrm{CPP}$ \\
\hline Glycine & $50 \mathrm{mM}$ Tris-citrate & $4^{\circ} \mathrm{C}$ & 30 & $100 \mathrm{nM}\left[{ }^{3} \mathrm{H}\right]$ glycine & $1 \mathrm{mM}$ glycine \\
\hline PCP & $50 \mathrm{mM}$ Tris-acetate & $25^{\circ} \mathrm{C}$ & 120 & $\left.10 \mathrm{nM} \mathfrak{[}^{3} \mathrm{H}\right] \mathrm{MK}-801$ & $10 \mu \mathrm{M}$ MK-801 \\
\hline AMPA & $\begin{array}{l}50 \mathrm{mM} \text { Tris- } \mathrm{Cl} \\
2.5 \mathrm{mM} \mathrm{CaCl}_{2}, \\
30 \mathrm{mM} \mathrm{KSCN}\end{array}$ & $4^{\circ} \mathrm{C}$ & 45 & $37 \mathrm{nM}\left[{ }^{3} \mathrm{H}\right] A \mathrm{APA}$ & $1 \mathrm{mM}$ glutamate \\
\hline Kainate & $50 \mathrm{mM}$ Tris-acetate & $4^{\circ} \mathrm{C}$ & 45 & $60 \mathrm{nM}\left[{ }^{3} \mathrm{H}\right]$ kainate & $100 \mu \mathrm{M}$ kainate \\
\hline Metabotropic & $\begin{array}{l}50 \mathrm{mM} \text { Tris-Cl, } \\
2.5 \mathrm{mM} \mathrm{CaCl}_{2}, \\
30 \mathrm{mM} \mathrm{KSCN}\end{array}$ & $4^{\circ} \mathrm{C}$ & 45 & $\begin{array}{c}82 \mathrm{nM}\left[{ }^{3} \mathrm{H}\right] \text { glutamate, } \\
100 \mu \mathrm{M} \text { NMDA, } \\
10 \mu \mathrm{M} \text { AMPA }\end{array}$ & $2.5 \mu \mathrm{M}$ quisqualate \\
\hline NNKQ & $\begin{array}{l}50 \mathrm{mM} \text { Tris- } \mathrm{Cl} \\
2.5 \mathrm{mM} \mathrm{CaCl}_{2}\end{array}$ & $4^{\circ} \mathrm{C}$ & 45 & $\begin{array}{c}82 \mathrm{nM}\left\{^{3} \mathrm{H}\right\} \text { glutamate, } \\
100 \mu \mathrm{M} \text { NMDA, } \\
2.5 \mu \mathrm{M} \text { quisqualate, } \\
1 \mu \mathrm{M} \text { kainate }\end{array}$ & $1 \mathrm{mM}$ glutamate \\
\hline
\end{tabular}

NMDA $=N$-methyl-D-aspartate; PCP $=$ phencyclidine; AMPA $=\alpha$-amino-3-hydroxy-5-methylisoxazole propionic acid; $\mathrm{NNKQ}=$ non-

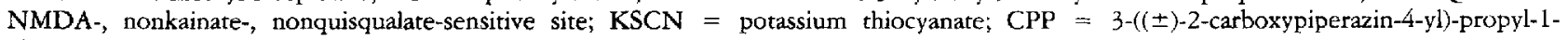
phosphonic acid.

was included. Specific binding for each assay was calculated by subtracting nonspecific binding density from the value obtained for total binding, and is expressed in femtomoles per milligram of protein. Triplicate sections were used for both total and nonspecific binding. Statistical analysis was performed using the StatView II software package (Abacus Concepts, Berkeley, CA).

\section{Results \\ Excitatory Amino Acid Receptor Subtypes \\ in Frontal Cortex}

Densitometry readings in the frontal cortex were done by sampling the entire cortical mantle. Comparison of binding between $\mathrm{HD}(\mathrm{n}=6)$ and control specimens $(\mathbf{n}=4$ ) revealed no significant difference for NMDA, glycine, MK-801, AMPA, metabotropic quisqualate, or kainate receptors (Student's $t$ test, $p>0.2$ ) (Fig 1). Binding to the NNKQ site was not determined in the frontal cortex.

By using regression analysis, no significant correlation with respect to either age or postmortem delay could be made for binding in any assay. This lack of correlation was true for both HD and control groups.

\section{Excitatory Amino Acid Receptor Subtypes in Caudate Nucleus}

Autoradiograms of EAA receptor binding in control human caudate revealed rather homogeneous binding in all assays, but this was not the case in the HD caudate (Figs 2 and 3). In the NMDA, AMPA, MK-801, kainate, metabotropic, and NNKQ assays, the binding in the HD caudate was nonuniform. To avoid sampling bias, data from large areas of the HD caudate were averaged, irrespective of inhomogeneities.

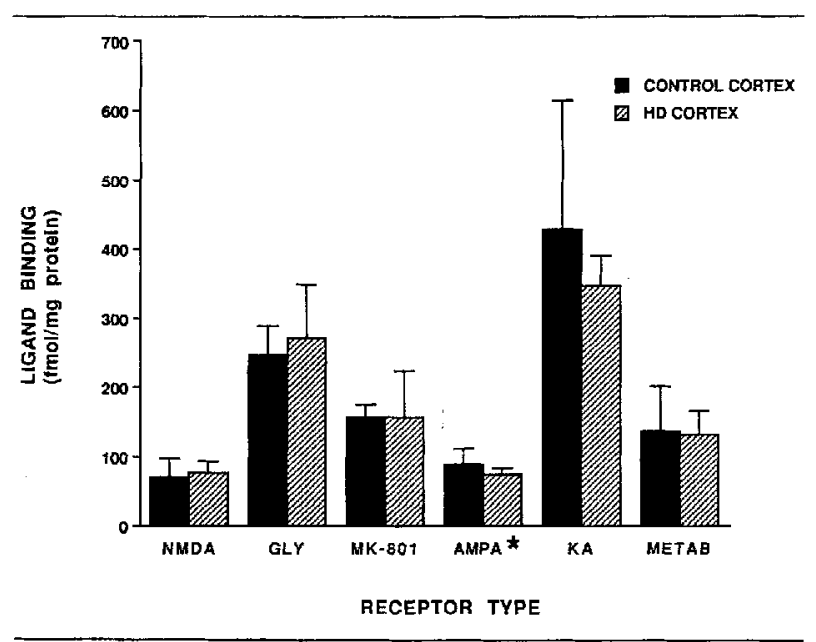

Fig 1. Comparison of ligand binding for the different assays in frontal cortex in control specimens (solid bars) and Huntington's disease (HD) specimens (hatched bars). Specific binding is expressed as femtomoles per milligram of protein. The asterisk denotes AMPA binding expressed as $10^{-1} \mathrm{fmol} / \mathrm{mg}$ of protein. $N M D A=N$-metbyl-D-aspartate; $G L Y=$ glycine; $A M P A=$ $\alpha$-amino-3-hydroxy-5-metbylisoxazole propionic acid; $K A=$ kainic acid; $M E T A B=$ metabotropic.

Figure 4 demonstrates the decrease in binding for all receptor types in $\mathrm{HD}$ caudate compared to control specimens. The decrease in binding was statistically significant for NMDA (51\%), glycine (54\%), MK-801 (55\%), AMPA (61\%), and kainate (55\%) assays (unpaired, two-tailed Student's $t$ test; $p<0.005$ ). Binding to the metabotropic receptor and the NNKQ site was decreased (31\% and $26 \%$, respectively) but not significantly $(p>0.1$ for the metabotropic receptor, $p>$ 

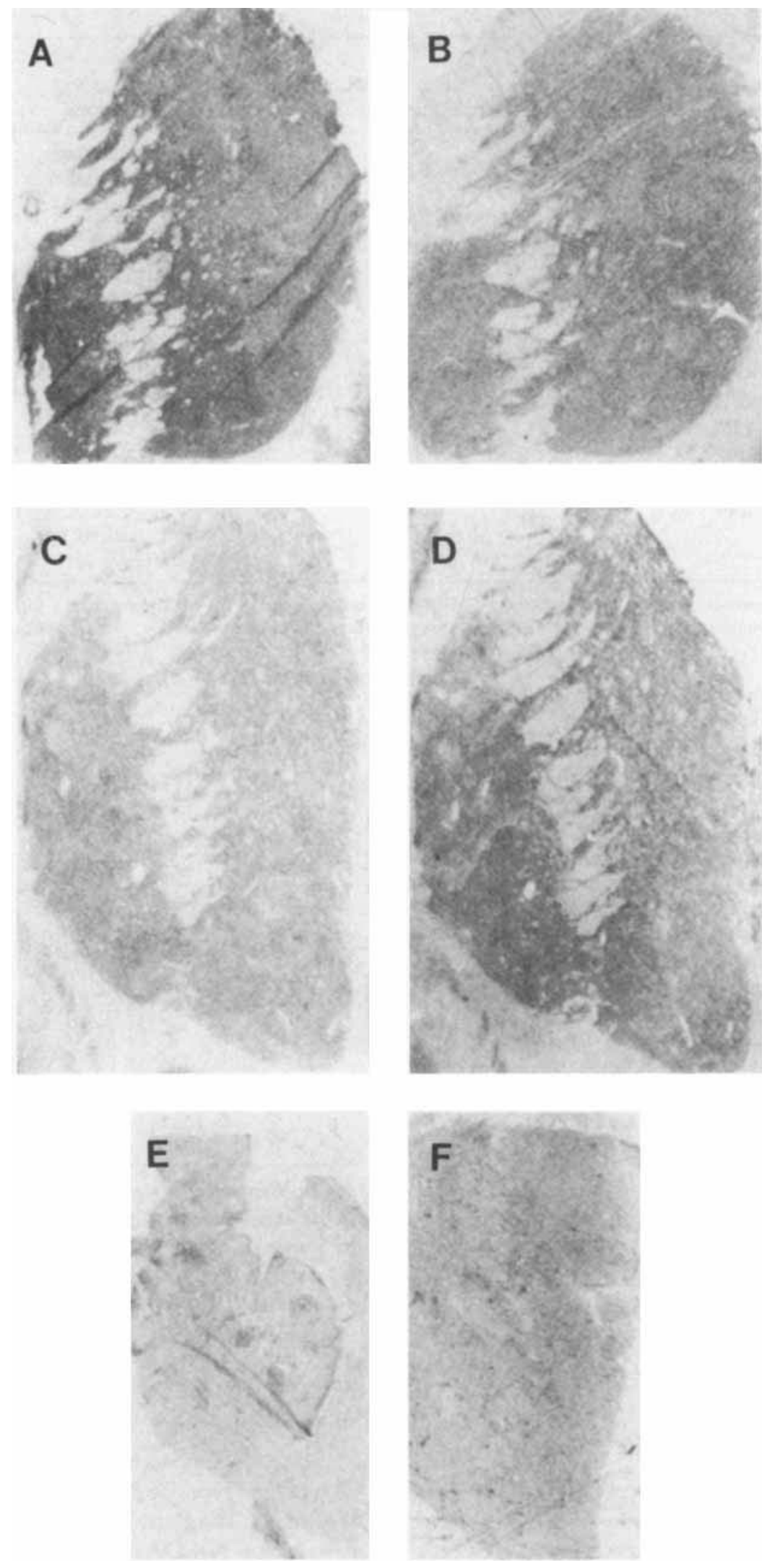

Fig 2. Autoradiograms of NMDA and the related phencyclidine $(P C P)$ receptor binding in control and Huntington's disease (HD) caudate. NMDA-sensitive ${ }^{3} H$ Hglutamate binding is sbown in control (A), HD grade 2 (C), and HD grade $4(E)$. Data from the entire area of the caudate nucleus were averaged to determine the density of binding. Binding to the ion-channel $P C P$ site with $\left({ }^{3} H\right) M K-801$ is seen in control $(B), H D$ grade $2(D)$, and HD grade 4 (F) specimens. Inbomogeneous NMDAsensitive $\left({ }^{3} \mathrm{H}\right)$ glutamate binding is especially apparent in grade $4 H D$ caudate (E). 

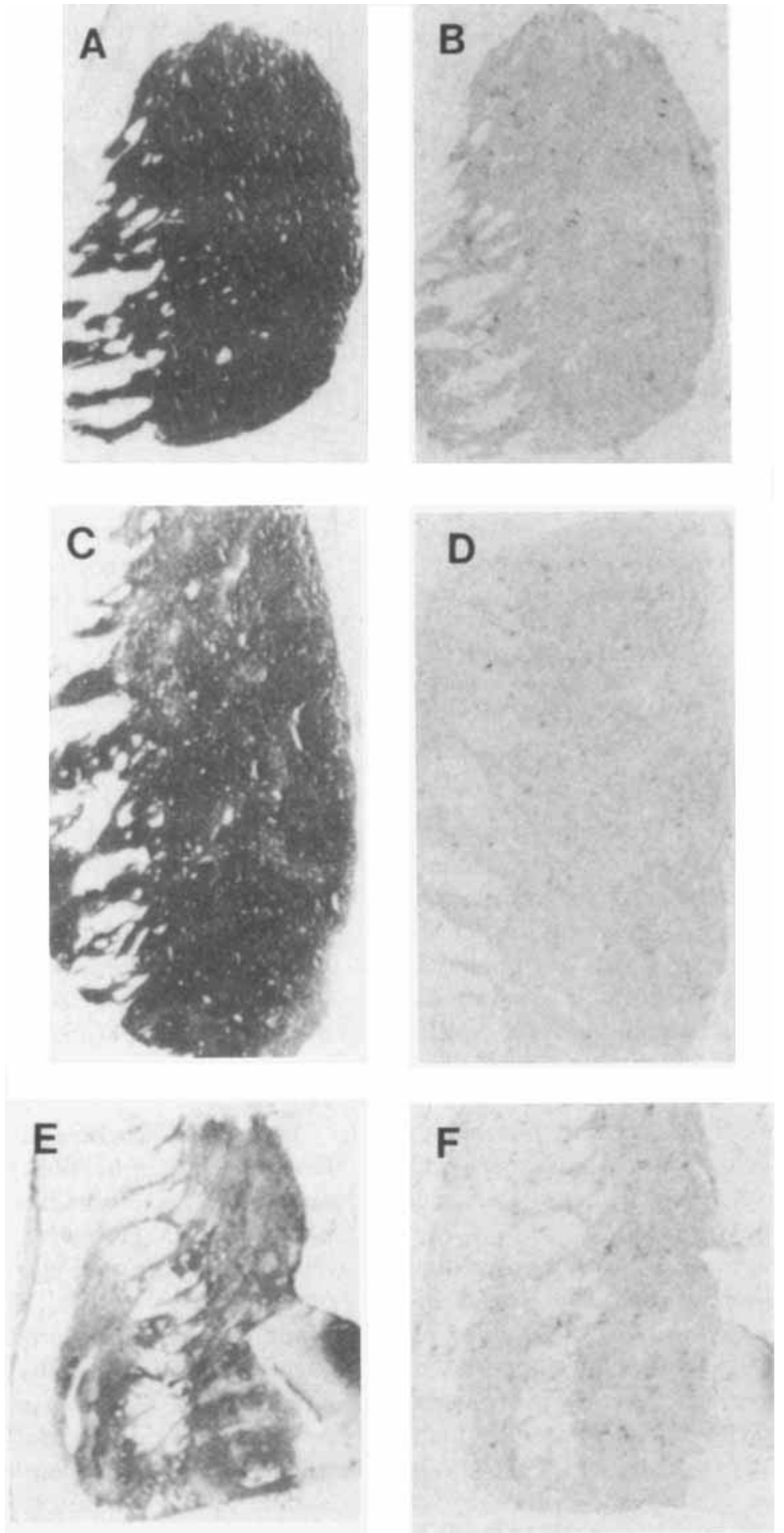

Fig 3. Binding to the non-NMDA receptors in control and Huntington's disease (HD) caudate is shown by quisqualatesensitive $\left({ }^{3} H\right) \alpha$-amino-3-bydroxy-5-metbylisoxazole propionic acid (AMPA) $(A, C$, and $E)$ and $\left({ }^{3} H\right)$ kainate $(B, D$, and $F)$ binding. Controls ( $A$ and $B$ ), grade $2 H D(C$ and $D)$, and grade $4 H D(E$ and $F)$ are illustrated. 


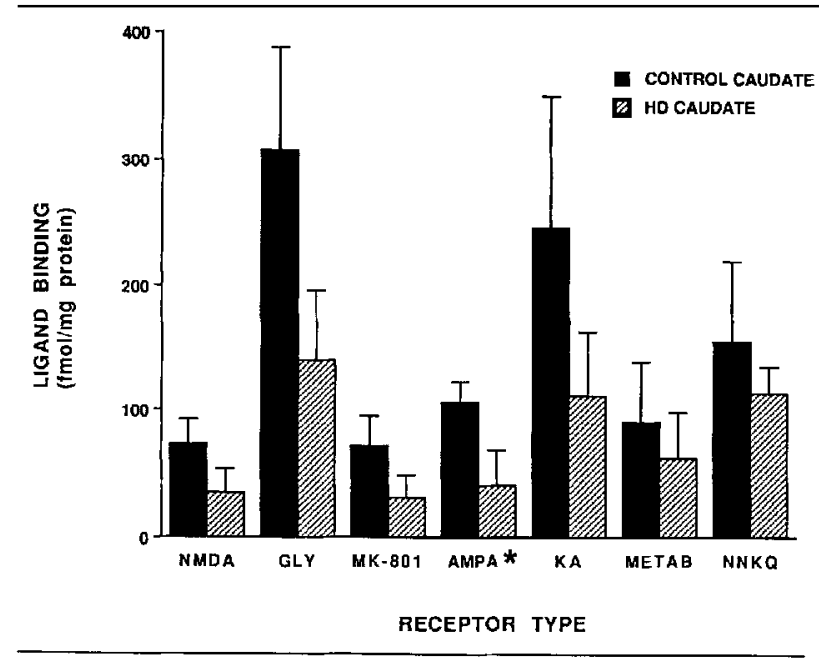

Fig 4. Comparison of ligand binding as determined by the different assays in caudate nucleus from control subjects (solid bars) and Huntington's disease (HD) patients (hatched bars). Specific binding is expressed as femtomoles per milligram of protein. The asterisk denotes AMPA binding expressed as $10^{-1} \mathrm{fmol} / \mathrm{mg}$ of protein. See legend to Fig 1 for explanation of most abbreviations. $N N K Q=$ non-NMDA-, nonkainate-, nonquisqualate-sensitive site.

0.2 for the NNKQ site). When data were analyzed for the effect of postmortem delay on receptor binding, no correlation could be determined by regression analysis for either control or HD brains in any of the assays. When the percentage decreases in binding in $\mathrm{HD}$ caudate were compared with results of the assays showing a significant loss of binding (NMDA, AMPA, kainate, glycine, and $\mathrm{MK}-801$ ) by one-way analysis of variance (ANOVA), there was no evidence of a selective loss of one receptor subtype compared to the others $(p>0.6)$. Similar analysis using only brains with Vonsattel grade 2 pathology $(\mathrm{n}=5)$ likewise revealed no selective loss of receptor binding.

In order to determine the effect of age on binding, multiple regression analysis was performed. In the control caudate, age was not correlated with binding for NMDA, glycine, MK-801, AMPA, metabotropic, or NNKQ site assays. There was, however, a significant positive correlation of age with kainate receptor binding in control caudate $\left(r^{2}=0.577, p<0.005\right)$. In contrast to this finding, binding for kainate $\left(r^{2}=\right.$ $0.215, p>0.2$ ), NMDA, metabotropic, or NNKQ site in $\mathrm{HD}$ caudate revealed no significant correlation with age, but a significant positive correlation existed for age and binding for glycine $\left(r^{2}=0.644, p<\right.$ $0.005)$, MK-801 $\left(r^{2}=0.398, p<0.05\right)$, and AMPA $\left(r^{2}=0.536, p<0.05\right)$. In the HD samples, there was a statistically significant negative correlation between age and grade $\left(r^{2}=0.695, p<0.001\right)$. Therefore, in an attempt to determine the relative contribution of age and grade to binding in $\mathrm{HD}$ caudate, grade was considered as a parametric variable in a multiple regression analysis. With this analysis, there was no consistent contribution of grade to the amount of binding.

\section{Discussion}

Results of previous experiments have suggested that EAA-induced neurotoxicity may contribute to the striatal pathology observed in HD [10-17, 19, 31]. Such neurotoxicity could result from excessive cortical input to striatum, abnormal striatal EAA receptors, excess endogenous EAA ligands, or the abnormal ability of striatal cells to cope with normal EAA receptor stimulation [28]. Quinolinic acid, a tryptophan metabolite, is a potent NMDA agonist that occurs normally in the human central nervous system. It was recently determined that in HD caudate, there is a potential for increased production of quinolinic acid [31]. Young and associates [28] reported a selective loss of NMDAsensitive receptors in HD putamen and Albin and coworkers [32] found a decrease of NMDA receptors in a presymptomatic HD brain. These latter findings suggested that perhaps NMDA receptors themselves are abnormal in HD. The purpose of the present study was to define more rigorously the changes in EAA receptors in HD using more selective assays. In the present study, pharmacologically defined NMDA, AMPA, and kainate receptors were decreased to the same degree in HD caudate. PCP and glycine sites, both associated with the NMDA receptor, were diminished similarly. Metabotropic and NNKQ binding sites were not significantly decreased, compared to binding sites in control specimens. There was no evidence of a selective loss of any single EAA receptor subtype in HD caudate.

Young and associates [28] reported that several different receptor types, both glutamatergic and nonglutamatergic, showed significant $(50-67 \%)$ decreases in binding in HD. However, NMDA-sensitive glutamate binding was decreased even more than was binding to other receptors $(>90 \%)$. Since an excitotoxic process would be expected to produce cell loss, and a consequent loss of receptors, the greater loss of the NMDA receptors was deemed consistent with the excitotoxic process occurring selectively at this class of receptor.

It is interesting to note that the decreases seen in binding to EAA receptors in the present study were comparable to the decrease in $\left[{ }^{3} \mathrm{H}\right] \mathrm{TCP}$ binding to the PCP receptor reported by Young and associates (approximately $50-60 \%$ in this study versus $67 \%$ in the previous one). Furthermore, although the lack of a selective loss of a receptor subtype is contradictory to the results of Young and associates, there are important differences between that study and this one. First, the previous analysis was carried out using HD putamen instead of caudate. A second distinction is that the assays for NMDA-sensitive and quisqualate-sensitive 
binding differ in the two studies. The assay for glutamate receptors performed by Young and associates determined NMDA-sensitive binding by incubating the tissue in a solution containing $20 \mathrm{nM}\left[{ }^{3} \mathrm{H}\right] g$ lutamate and $2.5 \mu \mathrm{M}$ quisqualate. Nonspecific binding was determined with $1 \mathrm{mM}$ glutamate, and specific binding was calculated by subtracting the nonspecific binding from the total binding under NMDA-sensitive conditions. A similar method was used to determine quisqualate-sensitive binding, by incubating the tissue in the presence of $100 \mu \mathrm{M}$ NMDA for total binding, and adding $2.5 \mu \mathrm{M}$ quisqualate for the determination of nonspecific binding. This technique of estimating quisqualate binding failed to distinguish between AMPAsensitive quisqualate binding and binding to the metabotropic receptor, and is a measure of binding to both sites. The fact that metabotropic receptors were not significantly decreased in the present study may in part explain the differential decrease in NMDA- versus quisqualate-sensitive sites observed in the previous study.

The assays used for binding to NMDA, glycine, MK-801, AMPA, metabotropic, and NNKQ sites have been extensively studied in our laboratory, and reflect the optimum conditions for detection of specific receptor subtypes. Binding of $\left[{ }^{3} \mathrm{H}\right]$ kainic acid to kainate receptors has been studied in homogenates of human control and HD brains, and suggests the presence of high-affinity and low-affinity kainate-binding sites. Total $\left[{ }^{3} \mathrm{H}\right]$ kainate binding was decreased by approximately $50 \%$ in $\mathrm{HD}$ compared to control specimens, but high-affinity kainate receptor binding was decreased by $90 \%$ in HD striatum $[33,34]$. For this study, total binding (including both high-affinity and low-affinity sites) of $\left[{ }^{3} \mathrm{H}\right]$ kainic acid was measured in the striatum. Our finding of a $55 \%$ decrease in total $\left[{ }^{3} \mathrm{H}\right]$ kainate binding is in accord with that of these previous studies. We are currently investigating the characteristics of high-affinity $\left[{ }^{3} \mathrm{H}\right]$ kainic acid binding in human striatum using quantitative in vitro receptor autoradiography.

We attempted to find a relationship between receptor binding, age, and pathological grade. The positive correlation between age and binding in HD caudate for glycine, MK-801, and AMPA may be explained by the contribution of pathological grade to the analysis. All of the grade $4 \mathrm{HD}$ brains were from patients less than 40 years old. There was a statistically significant negative correlation between age and grade $\left(r^{2}=\right.$ $0.695, p<0.001)$ in the HD brains. The correlation between age and grade could explain why the older HD patients (with less severe pathology) had apparently higher amounts of receptor binding. This negative correlation of age and grade is in accord with the clinical feature of HD that patients who die at an earlier age have more advanced pathology [35]. When parhological grade was treated as a parameter, neither grade nor age was consistently a significant determinant of binding. Clarification of this issue will require a larger number of samples representing each pathological grade, to allow for a more sophisticated statistical analysis.

An intriguing finding in this study is the pattern of binding to the NMDA, MK-801, AMPA, kainate, metabotropic, and NNKQ receptors in HD caudate. While the autoradiograms of control caudates showed some heterogeneity of binding throughout the substance of the caudate, the HD caudates exhibited more pronounced inhomogeneous labeling of receptors, a finding noted previously $[27,36]$. Recent reports of synaptophysin and calcineurin immunoreactivity in HD caudate demonstrated a similar inhomogeneity of cell loss [37, 38]. It is known that the striatum is a heterogeneous structure composed of regions staining lightly for acetylcholinesterase (striosomes) surrounded by regions with relatively darker staining (matrix) [39-41]. The afferent and efferent connections of striosomes differ from those of the matrix [42, 43]. Immunohistochemical evidence would suggest that projections from the matrix are initially affected in HD. The demonstration by Reiner and associates [44] that matrix enkephalinergic projections to the external globus pallidus and matrix substance $\mathrm{P}$ projections to substantia nigra pars reticulata are lost early in $\mathrm{HD}$, with relative sparing of substance $\mathrm{P}$-containing projections to the internal globus pallidus (originating in the striosomes), is consistent with this hypothesis. To determine if the inhomogeneous binding to glutamatergic receptors in $\mathrm{HD}$ caudates is related to the striosomematrix compartments, acetylcholinesterase staining of caudate sections adjacent to those used for autoradiography is being performed in our laboratory.

The examination of glutamatergic receptor binding in control and HD frontal cortex did not demonstrate any significant changes, compared to control specimens. This finding is consistent with those of Young and associates, who actually observed a slight increase in binding under NMDA- and quisqualate-sensitive conditions. These results are also in agreement with those of Reynolds and colleagues [45], who determined that there was no significant change in choline acetyltransferase or EAA levels in homogenates of cerebral cortex from demented patients with $\mathrm{HD}$, when compared to control specimens.

The observed losses in caudate of NMDA, AMPA, and kainate receptors may simply reflect neuronal cell loss. The metabotropic and NNKQ sites showed a less pronounced decrease in binding in HD compared to NMDA, AMPA, and kainate receptor binding. The cellular localization of the metabotropic site within the striatum is unknown, whereas NMDA, AMPA, kainate, and NNKQ receptors are postsynaptic, and lo- 
cared on the medium-sized spiny neurons $[25,46]$. If the metabotropic receptors are not situated on medium-sized spiny neurons, then the changes in receptor binding would be less than for the other receptors. The physiological correlate and significance of changes in the NNKQ binding site are unknown. Further analysis of the discrepancy in binding loss among EAA receptors will require characterization of the physiology and pharmacology of the metabotropic and NNKQ binding sites.

To delineate the pattern of degeneration in $\mathrm{HD}$, further studies are needed to better characterize the immunohistochemical features of HD striatum. Attempts to correlate the autoradiographic demonstration of inhomogeneities in EAA receptor binding to known striosome and/or matrix markers are required to determine whether neuronal degeneration in $\mathrm{HD}$ occurs coincident to an anatomical or neurochemical pattern. A striosome-specific marker, when available for use in human tissue, could be used with other markers to characterize the striosomes and matrix in both normal and diseased striatum. By combining autoradiographic binding studies with immunohistochemical techniques, there will be a better understanding of the pathophysiology of $\mathrm{HD}$.

This work was supported by the Huntington's Disease Society of America (for L. S. D.), and United States Public Health Service grants NS 15655, NS 19613, and AG 08671 (to A. B. Y. and J. B. P.).

The authors wish to thank Zane Hollingsworth, Sharin Sakurai, Dr Roger Albin, and Dr Jang-Ho Cha, who provided assistance and guidance in this project. Dr Albin also critically reviewed the manuscript.

\section{References}

1. Folstein SE. Huntington's disease. A disorder of families. Baltimore, MD: The Johns Hopkins University Press, 1989:13-66

2. Vonsattel J-P, Myers RH, Stevens TJ, et al. Neuropathological classification of Huntington's disease. I Neuropathol Exp Neurol 1985;44:559-577

3. Roos RAC, Pruyt JFM, de Vries J, Bots GThAM. Neuronal distribution in the putamen in Huntington's disease. J Neurol Neurosurg Psychiatry 1985;48:422-425

4. De la Monte SM, Vonsattel J-P, Richardson EP. Morphometric demonstration of atrophic changes in the cerebral cortex, white matter, and neostriatum in Huntington's disease. J Neuropathol Exp Neurol 1988;47:516-525

5. Kowall NW, Ferrante RJ, Martin JB. Patterns of cell loss in Huntington's disease. Trends Neurosci 1987;10:24-29

6. Haber SN. Neurotransmitters in the human and nonhuman primate basal ganglia. Hum Neurobiol 1986;5:159-168

7. Choi DW, Rothman SM. The role of glutamate neurotoxicity in hypoxic-ischemic neuronal death. Annu Rev Neurosci 1990;13:171-182

8. Stewart GR, Zorumski CF, Price MT, Olney JW. Domoic acid: a dementia-inducing excitotoxic food poison with kainic acid receptor specificity. Exp Neurol 1990;110:127-138

9. Spencer PS, Ludolph A, Dwivedi MP, et al. Lathyrism: evidence for role of the neuroexcitatory amino acid BOAA. Lancet 1986;2:1066-1067

10. Nunn PB, Seelig M, Zagoren JC, Spencer PS. Stereospecific acute neuronotoxicity of "uncommon" plant amino acids linked to human motor-system diseases. Brain Res 1987;410:375-379

11. McGeer EG, McGeer PL. Duplication of biochemical changes of Huntington's chorea by intrastriatal injections of glutamic and kainic acids. Nature 1976;263:517-519

12. Coyle JT, Schwarcz R. Lesion of striatal neurones with kainic acid provides a model of Huntington's chorea. Nature 1976; 263:244-246

13. Coyle JT, Molliver ME, Kuhar MJ. In situ injection of kainic acid: a new method for selectively lesioning neuronal cell bodies while sparing axons of passage. J Comp Neurol 1978;180: 301-324

14. Marasigan SM, Sato M, Miyoshi K. Experimental striatal degeneration induced by kainic acid administration: relevance to morphological changes in Huntington's disease. Jpn J Psychiatry Neurol 1986;40:113-122

15. Schwarce R, Whetsell WO, Mangano RM. Quinolinic acid: an endogenous metabolite that produces axon-sparing lesions in tat brain. Science 1983;219:316-318

16. Beal MF, Kowall NW, Ferrante RJ, Cipolloni PB. Quinolinic acid striatal lesions in primates as a model of Huntington's disease. Ann Neurol 1989;26:137

17. Difighia M. Excitotoxic injury of the neostriatum: a model for Huntington's disease. Trends Neurosci 1990;13:286-289

18. Beal MF, Kowall NW, Ellison DW, et al. Replication of the neurochemical characteristics of Huntington's disease by quinolinic acid. Nature 1986;321:168-171

19. Beal MF, Kowall NW, Swartz KJ, et al. Differential sparing of somatostatin-neuropeptide $Y$ and cholinergic neurons following striatal excitotoxin lesions. Synapse 1989;3:38-47

20. Greenamyre JT, Young AB, Penney JB. Quantitative autoradiographic distribution of $\left.\mathrm{L}-{ }_{[}^{3} \mathrm{H}\right]$ glutamate-binding sites in rat central nervous system. J Neurosci 1984;4(8):2133-2144

21. Wood PL, Rao TS, Iyengar S, et al. A review of the in vitro and in vivo neurochemical characterization of the NMDA/PCP/ glycine/ion channel receptor macrocomplex. Neurochem Res 1990;15:217-230

22. Greenamyre JT, Olson JMM, Penney JB, Young AB. Autoradiographic characterization of $N$-methyl-D-aspartate-, quisqualate- and kainate-sensitive glutamate binding sites. J Pharmacol Exp Ther 1985;233:254-263

23. Monaghan DT, Bridges RJ, Corman CW. The excitatory amino acid receptors: their classes, pharmacology, and distinct properties in the function of the central nervous system. Annu Rev Pharmacol Toxicol 1989;29:365-402

24. Cha JJ, Makowiec RL, Penney JB, Young AB. $\left.\mathrm{L}_{-[}^{-3} \mathrm{H}\right]$ Glutamate labels the metabotropic receptor in rodenc brain. Neurosci Lett 1990;113:78-83

25. Greenamyre JT, Higgins DS, Young AB, Penney JB. Regional ontogeny of a unique glutamate recognition site in rat brain: an autoradiographic study. Inc J Dev Neurosci 1990;8:437-445

26. Penney JB, Young AB. Quantitarive autoradiography of neurotransmitter receptors in Huntington disease. Neurology 1982; 32:1391-1395

27. Greenamyre JT, Penney JB, Young AB, et al. Alterations in L-glutamate binding in Alzheimer's and Huntington's diseases. Science 1985;227:1496-1499

28. Young AB, Greenamyre JT, Hollingsworth $Z$, et al. NMDA receptor losses in putamen from patients with Huntington's disease. Science 1988;241:981-983

29. Palacios JM, Niehoff DL, Kuhar MJ. Receptor autoradiography with tritium-sensitive film: potential for computerized densitometry. Neurosci Lett 1981;25:101-105

30. Rainbow TC, Bleisch WV, Biegon A, McEwen BS. Quantitative 
densitometry of neurotransmitter receptors. $\mathrm{J}$ Neurosci Methods 1982;5:127-138

31. Schwarcz R, Okuno E, White RJ, et al. 3-Hydroxyanthranilate oxygenase activity is increased in the brains of Huntington disease victims. Proc Natl Acad Sci USA 1988;85:4079-4081

32. Albin RL, Young AB, Penney JB, et al. Abnormalities of striatai projection neurons and $N$-methyl-D-aspartate receptors in presymptomatic Huntington's disease. N Engl J Med 1990;322: $1293-1298$

33. Beaumont K, Maurin Y, Reisine TD. Huntington's disease and its animal model: alterations in kainic acid binding. Life Sci 1979;24:809-816

34. London ED, Yamamura HI, Bird ED, Coyle JT. Decreased receptor-binding sites for kainic acid in brains of patients with Huntington's disease. Biol Psychiatry 1981;16:155-162

35. Myers RH, Vonsattel JP, Stevens TJ, et al. Clinical and neuropathologic assessment of severity in Huntington's disease. Neurology 1988;38:342-347

36. Penney JB, Young AB. Striatal inhomogeneities and basal ganglia function. Mov Disord 1986;1:3-15

37. Goto S, Hirano A. Synaptophysin expression in the striatum in Huntington's disease. Acta Neuroparhol (Berl) 1990;80:88-91

38. Goto S, Hirano A, Rojas-Corona RR. An immunohistochemical investigation of the human neostriatum in Huntington's disease. Ann Neurol 1989;25:298-304

39. Graybiel AM, Ragsdale CW, Yoneoka ES, Elde RP. An immunohistochemical study of enkephalins and other neuropeptides in the striatum of the cat with evidence that the opiate peptides are arranged to form mosaic patterns in register with the striosomal compartments visible by acetylcholinesterase staining. Neuroscience 1981;6:377-397

40. Hirsch EC, Graybiel AM, Hersh LB, et al. Striosomes and extrastriosomal matrix contain different amounts of immunoreactive choline acetyltransferase in the human striatum. Neurosci Lett 1989;96:145-150

41. Graybiel AM. Correspondence between the dopamine islands and striosomes of the mammalian striatum. Neuroscience 1984; 13:1157-1187

42. Gerfen CR. The neostriatal mosaic: compartmentalization of corticostriatal input and striatonigral output systems. Narure 1984:311:461-464

43. Gerfen CR. The neostriatal mosaic: striatal patch-matrix organization is related to cortical lamination. Science 1989;246:385388

44. Reiner A, Albin RL, Anderson KD, et al. Differential loss of striatal projection neurons in Huntington disease. Proc Natl Acad Sci USA 1988;85:5733-5737

45. Reynolds GP, Pearson SJ, Heathfield KWG. Dementia in Huntington's disease is associated with neurochemical deficits in the caudate nucleus, not the cerebral cortex. Neurosci Lett 1990; 113:95-100

46. Greenamyre JT, Young AB. Synaptic localization of striatal NMDA, quisqualate and kainate receptors. Neurosci Lett 1989; 101:133-137 